\title{
The Look of a
}

Woman 
This page intentionally left blank 


\section{ERIC PLEMONS}

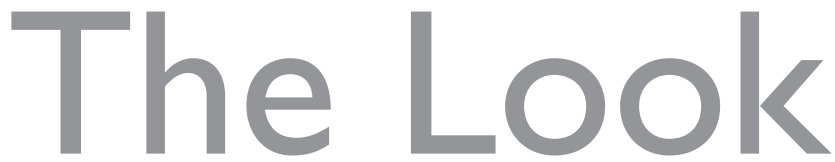

Facial Feminization Surgery and

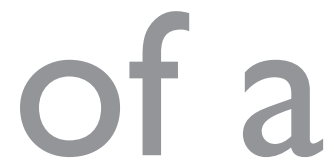

the Aims of Trans- Medicine

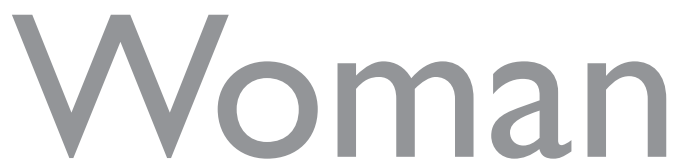

Duke University Press $\quad$ Durham and London 2017 
(C) 2017 DUKe UnIVERSITY PRESS. All rights reserved Printed in the United States of America on acid-free paper $\infty$ Interior designed by Courtney Leigh Baker Cover designed by Amy Ruth Buchanan Typeset in Whitman and Gill Sans by Copperline

Library of Congress Cataloging-in-Publication Data Names: Plemons, Eric, [date] author.

Title: The look of a woman : facial feminization surgery and the aims of trans- medicine / Eric Plemons. Description: Durham : Duke University Press, 2017. | Includes bibliographical references and index. Identifiers:

LCCN 2017001910 (print)

LCCN 2017006457 (ebook)

IS BN 9780822368861 (hardcover : alk. paper)

IS BN 9780822369141 (pbk. : alk. paper)

IS BN 9780822372707 (ebook)

Subjects: LCSH: Male-to-female transsexuals-United States. | Sex change-United States. | Face-SurgeryUnited States. | Surgery, Plastic-United States.

Classification: LCC HQ77.95.U6 P54 2017 (print)| LCC HQ77.95.U6 (ebook)| DDC 306.76/8-dc23 LC record available at https://lccn.loc.gov/2017001910

Cover art: Annes Bil, Face Line Drawing, 2014. Continuous line drawing; pencil on paper. 
For Anne 
This page intentionally left blank 